\title{
A test of grazing compensation and optimization of crested wheatgrass using a simulation model
}

\author{
BRET E. OLSON, RICHARD L. SENFT, AND JAMES H. RICHARDS
}

\section{Abstract}

We developed a simulation model based on tiller population processes to test graxing compensation and optimization in crested wheatgrass (Agropyron desertorum (Fisch. ex Link) Schult.). Model functions describing tiller dynamics and growth were derived from field observations in west-central Utah. Predicted tiller growth and new tiller production following defoliation were verified againat additional data from the same site; total production was valldated againat a 30-year-old data set from a different site. We then simulated 2 grazing experiments. First, grazing compensation was determined as a function of the timing of a single defoliation during the growing season. Response variables included tiller density, plot growth rates, standing crop, and seasonal production. Second, graxing optimization, a combination of graxing frequency and intensity that increases primary production above that of ungrazed plants, was asseased by the systematic varintion of these defoliation parameters under simulated dry, average, and wet winters (September-May). Results of the first experiment indicated that compensation depended mainly on the timing of defoliation, presumably because of phenological constraints to regrowth and the short growing season in this cold-desert region. Overcompensation only occurred when plants were defoliated before the traditional start of the graxing sesson. Although defoliation increased tiller growth rates, the second experiment failed to reveal an optimum combination of defoliation frequency and intensity resulting in maximum biomass production except after a dry winter. Results from the second experiment indicated that implementing intensive rotational graxing systems will seldom increase crested wheatgrass production in these cold-desert systems.

Key Words: Agropyron desertorum, tiller, defoliation, ramets, ramet population model, production model

A short spring growing season constrains the extent and timing of primary productivity on cold-desert regions of the world (West 1983). In many of these regions the native tussock grasses have not evolved tolerance to large mammalian herbivory (Mack and Thompson 1982). Because many native grasses in western North America are sensitive to spring livestock grazing, grazing-tolerant tussock grasses from Eurasia, primarily of the Triticeae, have been widely established. Most notably, crested wheatgrass (Agropyron desertorum (Fisch. ex Link) Schult.) has been seeded to provide early spring forage and to control soil erosion (Rogler and Lorenz 1983). On cold-desert rangelands where it has been established, growth is usually cued to short ( 2 to 3 month) periods of adequate temperature, nutrient availability, and soil moisture. Soil moisture

\footnotetext{
Authors are research associate, Reclamation Research Unit, Montana State University, Bozeman 59717; research ecologist, USDA ARS, South Central Family Farm Research Center, Booneville, Arkansas 72927; and associate professor, Department of Range Science and the Ecology Center, Utah State University, Logan 84322-5230. At the time of the research, the first author was research assistant, Department of Range Science, Utah State University. The second author was assistant professor, Department of Animal; Dairy, and Veterinary Sciences, Utah State University.

The Utah Agricultural Experiment Station (Project 780) and the National Science Foundation (BSR-8207171 and BSR-8705492) supported our research. This is Journal Paper No. 3439 of the Utah Agricultural Experiment Station, Utah State University, Logan. We thank J.L.K. Pedersen for field assistance and $M$. Andrew, $M$. Coughenour, D. Pyke, H. Thorgeirsson, and two anonymous reviewers for constructive comments on the manuscript.

Manuscript accepted 24 April 1989.
}

recharge from winter snow is the primary suurce of water for spring growth (Caldwell 1985).

Traditionally, these established grasses have been managed extensively, e.g., continuous season-long grazing, but there has been interest in intensifying grazing management of these species (Malechek and Dwyer 1983). With extensive or minimal management, grazing is highly variable in space and time, whereas intensive management should increase control over the critical factors of the timing, intensity, and frequency of defoliation.

With extensive management most tussocks of crested wheatgrass are grazed only once, on average, during the growing season (Norton and Johnson 1983). Yet because pastures are grazed incrementally, individual tussocks are defoliated at different phenological stages. The response of a tussock grazed in early spring differs considerably from the response of a neighboring tussock grazed in late spring (Richards and Caldwell 1985). McNaughton (1983) suggested that plants defoliated early in the growing season when soil moisture and nutrient levels are high can compensate for foliage removed by grazers. We define compensation as the ability of a grazed plant to maintain a similar level of production as an ungrazed plant (after Belsky 1986). Compensation equal to or greater than ungrazed plants has been observed after early spring defoliations of crested wheatgrass (Miller et al. 1984, Olson and Richards 1988a). Early spring defoliations resulting in compensation occur just before the grasses begin their rapid growth phase. Thus, only relatively small increases in tiller growth rates are needed to achieve compensation (Hilbert et al. 1981). Compensation following grazing must be assessed carefully because grazing affects other ecosystem processes (Belsky 1987); for example, the status of neighboring plants can alter the response of grazed plants to the physical loss of foliage (Mueggler 1972, Olson and Richards 1989).

With intensive management grasses may be grazed several times within a growing season. To justify the costs of implementing an intensive system, the increased control over grazing intensity and frequency should maximize primary production and ultimately livestock production by enhancing regrowth. Evidence for and against grazing compensation has often come from African $\mathrm{C}_{4}$ sedges and grasses clipped or grazed at frequent, 2- to 14-day, intervals (McNaughton 1979, 1985; Belsky 1986). Whether the $C_{3}$ crested wheatgrass can withstand such short grazing intervals is unknown. Hilbert et al. (1981) hypothesized that frequent grazing is unlikely to result in compensation because large increases in relative growth rates would be needed after each grazing event.

With one notable exception (Cook et al. 1958), time and cost constraints have prohibited experiments to determine tussock grass response to the numerous permutations of grazing intensity and frequency that occur in intensive systems. Because the growth and development of tussock grasses are fairly deterministic functions of the number and size of tillers, both of which are affected by grazing, simulation modeling of tiller population processes may allow experiments combining grazing intensity and frequency at minimal cost.

We developed a model based on weekly observations of the growth and population dynamics of grazed and ungrazed tillers in 
a short-duration system (Olson and Richards 1988a). Although the structure of the model did not include other factors associated with grazing, i.e., trampling, nutrient cycling, altered competitive backgrounds, these factors are implicitly included in the model because the data used to develop the model were from a field study of crested wheatgrass response to grazing by cattle (Olson and Richards 1988a,b).

Once validated, we used the model to assess compensation of crested wheatgrass following a single defoliation at various times during the spring growing season. We also simulated a factorial experiment (defoliation intensity and frequency, and precipitation) to determine if an optimal combination of non-zero defoliation parameters could be used in a grazing system on crested wheatgrass. These results were compared with McNaughton's (1979) grazing optimization hypothesis.

\section{Model Conceptualization}

Tussocks of crested wheatgrass consist of metapopulations of tillers (sensu White 1979). The emergence, growth, and death of tillers represent whole tussock response to the environment. Hence, a model of tiller population processes integrates the physiological and morphological attributes that are manifested in tussock growth. Our simulation model was based on observations describing growth rates of different types of tillers and the transfer of tillers among population classes. Tillers were divided into 3 classes: undefoliated parent tillers, defoliated parent tillers, and new spring tillers. The latter were subdivided into cohorts (tiller pulses) produced following individual defoliation events.

In a normal year, almost all tillers of crested wheatgrass present in early spring were produced the previous fall, overwinter with 1 to 3 leaves, and resume growth in late March or early April. The growing season begins with the spring growth of overwintered tillers. In the model, we started spring growth on 1 April. All tillers are undefoliated parent tillers at this time. Grazing converts these tillers to defoliated parent tillers. Subsequent forage production depends on the growth of the undefoliated tillers, the regrowth of defoliated tillers, or the emergence and growth of new spring tillers (Olson and Richards 1988a). All tillers senesce by mid-July when soil moisture is depleted.

\section{Model Development}

Spring growth and regrowth of crested wheatgrass were simulated as functions of winter precipitation (September-May), and the timing (relative to the initiation of growth) and intensity of a single defoliation event. The model operated on a daily time step and was based on changes in the number and size (height and weight) of undefoliated, defoliated, and new spring tillers through time.

Functions describing the growth of tillers of crested wheatgrass were derived from nondestructive measurements by Olson and Richards (1988a). In summary, ungrazed tillers grew slowly until early May, then rapidly until mid-June when inflorescences were fully developed. Grazing before mid-May often enhanced tiller growth, whereas grazing after mid-May usually reduced tiller growth. Grazing from mid-May to mid-June stimulated the production of new spring tillers.

The daily height growth increment $\left(\mathrm{mm} \mathrm{d}^{-1}\right)$ of undefoliated tillers $(\Delta H)$ was simulated by:

$$
\Delta H=H_{\mathbf{t}} * B_{\text {realiead }}
$$

where $H_{t}$ was tiller height (mm) at time.t, $t$ was time since growth initiation, and $B_{\text {realized }}\left(\mathrm{mm} \mathrm{mm}^{-1} \mathrm{~d}^{-1}\right)$ was actual height growth

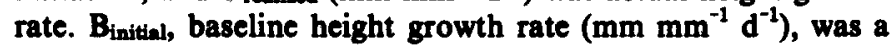
function of winter precipitation ( $P$ in $\mathrm{mm}$ ):
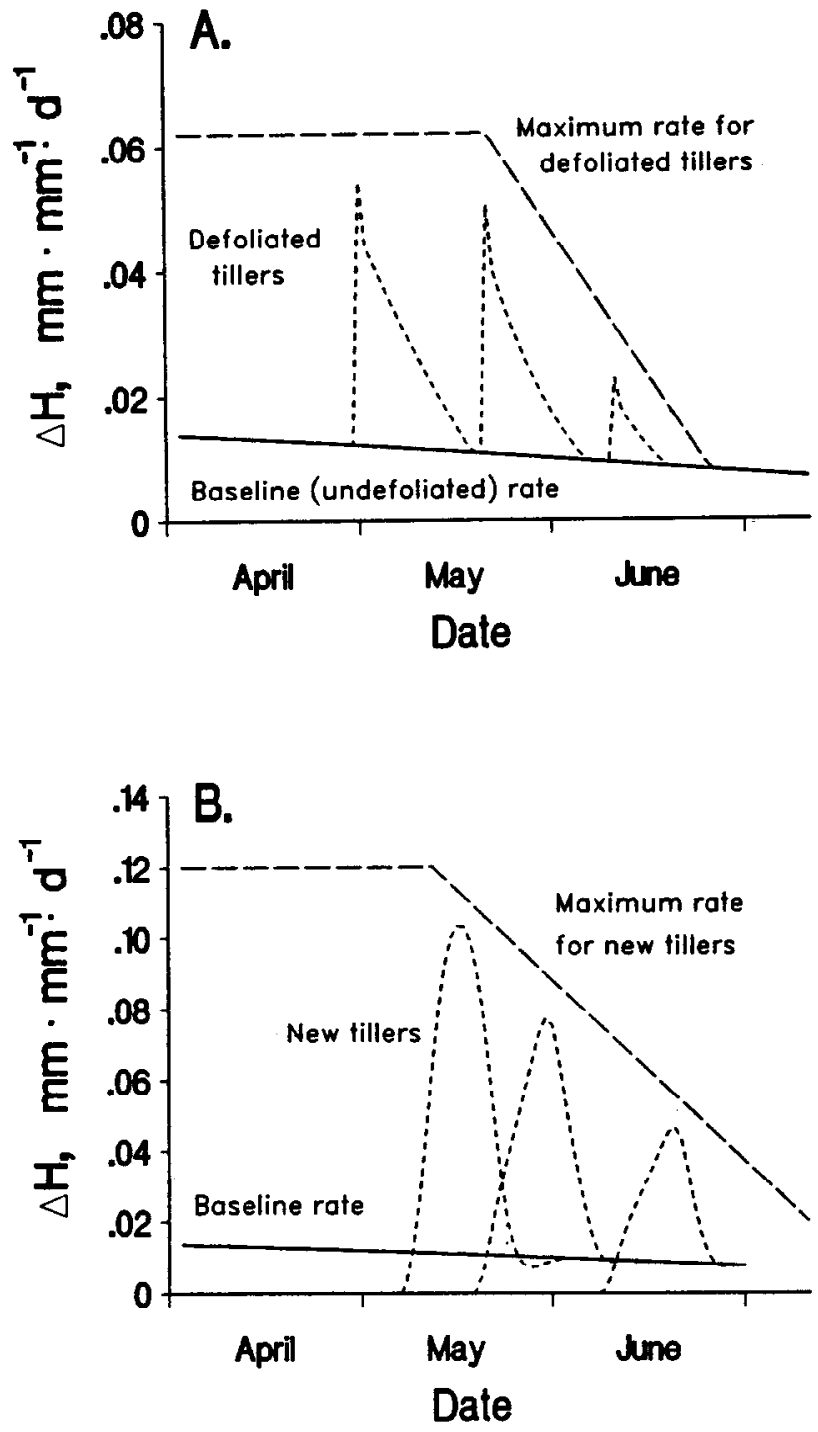

Fig. 1. Height growth rates of a defoliated tillers and b. new tillers. These figures represent simulated growth rates for a moderately wet winter (350 $\mathrm{mm}$ ). Plots were defoliated 30, 50, and 70 days after the initiation of growth. Note different scales.

$$
B_{\text {initial }}=0.000048 \mathrm{~mm} \mathrm{~d}^{-1} * P
$$

The realized growth rate declined linearly from the initial rate throughout the active growth phase (Fig. la), depending on the multiplier ZMOD which integrated the growth of all tiller cohorts (see equation 4). Height-growth rate varied among years with precipitation. The height-growth function operated until a maximum height based on the preceding winter precipitation was reached, and then growth stopped abruptly, similar to our field observations. Maximum tiller height $\left(\mathrm{H}_{\max }\right)$ was calculated from a correlation between observed heights and winter precipitation.

$$
H_{\max }=1.1 * P
$$

Height growth was further modified by negative feedback from biomass growth:

$$
\mathrm{ZMOD}=1-\mathrm{BM}_{\mathrm{t}} *\left(1.5 * \mathrm{BM}_{\operatorname{mex}}\right)^{-1}
$$

where ZMOD was a modifier to height growth which varied between 0 and $1, B_{1}$ was current total biomass $(\mathrm{kg} / \mathrm{ha})$, and 

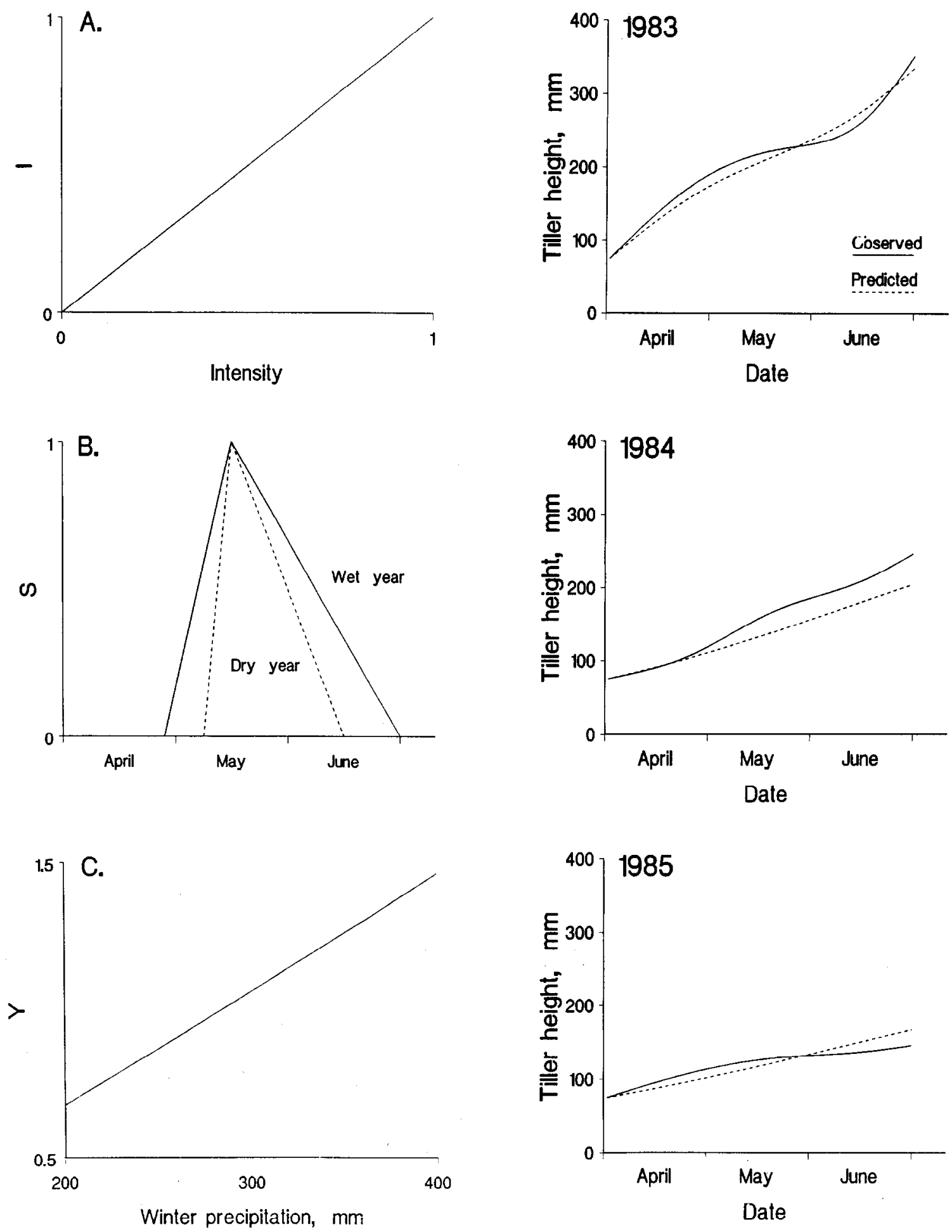

Fig. 2. Three of the factors which controlled the size of a tillering pulse in the model: $a$ defoliation intensity $(I), b$. date of defoliation within the growing season (S), c. September-May precipitation $\left(Y, Y=0.002 * P^{1.1}\right.$ where $P$ is precipitation in $\mathrm{mm}$ ). $I, S$, and $Y$ are dimensionless scalars.

$\mathrm{BM}_{\max }$ was the total biomass supported under a given precipitation regimen. $\mathbf{B M}_{\max }$ was estimated by:

$$
\mathrm{BM}_{\max }=1.11 * \mathrm{BM}_{\text {avo }} * \mathrm{P} *\left(\mathbf{P}_{\text {ave }}\right)^{-1}
$$

where longterm average biomass production, $\mathbf{B M}_{\mathrm{ave}}$, and winter precipitation, $P_{\text {ave, }}$ were $900 \mathrm{~kg} / \mathrm{ha}$ and $300 \mathrm{~mm}$, respectively (modified from Sneva and Hyder 1961).

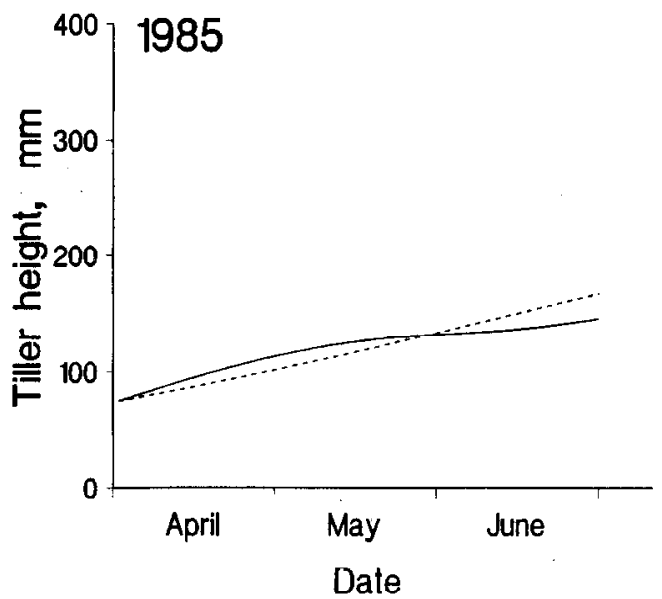

Fig. 3. Observed and predicted growth (height $\mathrm{mm}$ ) of undefoliated tillers from 1 April to 10 July. Observed data are means of 150 tillers in 1983 (10 tillers/plant, 15 plants) and 100 tillers (10 tillers/plant, 10 plants) in 1984 and 1985; adapted from Olson 1986.

During regrowth following defoliation, height growth rate (mm $\mathrm{mm}^{-1} \mathrm{~d}^{-1}$ ) of defoliated parent tillers was immediately enhanced and then declined over a 3-week period to the baseline rate (Fig. 1a, Olson and Richards 1988a). Peak height growth rate following defoliation declined as the season progressed. Defoliated tillers ceased growth at the end of the spring growing season 10-15 days earlier than undefoliated tillers. 
New spring tillers were $20 \mathrm{~mm}$ in length within the leaf sheaths of their progenitors before defoliation (from Mueller and Richards 1986). Their subsequent growth was initially equal to that of parent tillers, increased over a 10-11 day period (maximum height growth rate $=0.12 \mathrm{~mm} \mathrm{~mm}^{-1} \mathrm{~d}^{-1}$ ), and then returned to rates comparable with parent tillers (Fig. 1b). The peak growth rate of new spring tillers, similar to defoliated tillers, declined as the season progressed.

Temperature was not explicitly included in the model. However, the empirically derived growth parameters in Equations 3, 4, and 5 implicitly included temperature effects. For example, high temperatures at our central Utah site probably depressed tiller growth rates late in the growing season (Busso 1988). Temperature effects, as in most cold-desert regions, were probably confounded with soil drying. Because spring growth was usually completed by mid-July, mid- and late-summer rains had little effect on spring production and thus were not included in the model.

Standing biomass of undefoliated parent tillers on tussocks was determined using a cumulative biomass (C)/cumulative height (A) formula developed for crested wheatgrass (Johnson 1987):

$$
\mathrm{C}=1.88 \mathrm{~A}-0.00888 \mathrm{~A}^{2}
$$

C and $A$ were expressed as proportions of their respective maximum values achieved in the spring growing season. A was defined as the cumulative height from the base of a tussock and $C$ was cumulative live biomass. $A$ and $C$ were converted to $\mathrm{mm}$ and $\mathrm{g}$ by scaling equations 3 and 5 .

For defoliated parent tillers and new spring tillers, allometric height-weight relationships were determined from biweekly harvests of tillers at soil level during the spring growing seasons of 1983-1985 (B. Olson 1986). Weights $\left(M_{t}\right)$ of defoliated parent tillers and new spring tillers were estimated daily from tiller height $\left(\mathrm{H}_{t}\right)$ measurements using power functions:

$$
\begin{gathered}
M_{t}=0.00032 * H_{t}^{1.11} \text { for defoliated tillers and } \\
M_{t}=0.00006 * H_{t}^{1.39} \text { for new tillers, }
\end{gathered}
$$

where the units of $M$ and $H$ were $g /$ tiller and $\mathrm{mm} /$ tiller, respectively. Standing biomass (kg/ha) was estimated for defoliated parent and new tillers as the product of tiller number and average mass per tiller. Standing biomass was estimated for each cohort of defoliated parent and new tillers.

Few tillers present in early spring senesce before the end of the growing season (unpublished data). Therefore, changes in total tiller numbers are primarily a function of a series of tillering pulses (additions) following defoliation. The addition of new tillers (NT) was calculated for each daily time step by:

$$
\mathrm{NT}=\mathrm{D}_{\mathrm{ct}} * \mathrm{RT}\left(\mathrm{D}_{\max }-\mathrm{D}_{\mathrm{ct}}\right) * \mathrm{D}_{\max }{ }^{-1}
$$

where $D_{c t}$ was the number in a single pulse of new tillers at time $t$, $D_{\max }$ was the maximum number of new tillers produced for a given pulse $c$, and RT was a growth rate constant. This logistic function was based on weekly observations of new spring tiller emergence following biweekly grazing events during spring (Olson and Richards 1988a). These observations indicated that the size of a tillering pulse $\left(D_{\max }\right.$ ) was controlled by 3 factors: the intensity and date of defoliations within the growing season, and the previous September-May precipitation. On average, tillering pulses lasted 21 days.

The intensity effect (I) on $D_{\max }$ was a monotonic function of defoliation intensity (Fig. 2a). Seasonal tillering potential (seasonal factor, S) rose from zero before 1 May, peaked on 20 May and declined to zero by late June (Fig. 2b). This factor was modified by winter precipitation. After wet winters defoliated parent tillers could produce new tillers earlier and later in the growing season, whereas after dry winters the tillering season was truncated (Fig. 2b). The precipitation effect $(Y)$ was defined as the maximum number of new tillers produced per defoliated parent tiller as a function of winter precipitation (Fig. $2 \mathrm{c}$ ). $\mathbf{N}$ was the number of defoliated parent tillers. Thus, the size of a tillering pulse was estimated as:

$$
D_{\max }=I * S * Y * N
$$

In simulations with multiple defoliations, the cumulative number of new tillers produced per parent was constrained to a maximum of 4.5 (from Mueller and Richards 1986). As the cumulative number of new tillers approached this limit, tiller pulse size was modified from equation 10 by:

$$
\text { TMOD }=1-\mathrm{D}_{\mathrm{cum}} *\left(4.5 * \mathrm{~N}_{\mathrm{cum}}\right)^{-1}
$$

where TMOD was a dimensionless factor varying between 0 and 1 , and $\mathrm{N}_{\text {cum }}$ and $\mathrm{D}_{\text {cum }}$ were cumulative numbers of defoliated parent tillers and of new tillers, respectively. To scale up to plot-level responses, initial tiller density was 535 tillers $/ \mathrm{m}^{2}$ (from B. Olson 1986). For seasonal biomass production and peak standing crop, these plot-level responses were scaled up to $\mathrm{kg} / \mathrm{ha}$.

\section{Model Validation}

\section{Methods}

Field observations of crested wheatgrass in 1983 and 1985 were used to develop and verify the model whereas data collected from the same site in 1984 provided a validation (Olson and Richards 1988a). Performance criteria were the quantitative correspondence of predicted height dynamics of defoliated and undefoliated tillers, and size of new tiller pulses to observed responses (Grant 1986).

Growth and regrowth were simulated for the springs of 1983, 1984, and 1985. Actual September-May precipitation was 380 $\mathrm{mm}, 351 \mathrm{~mm}$, and $309 \mathrm{~mm}$ in 1983-1985. Initial parent tiller heights were set to $75 \mathrm{~mm}$ (B. Olson 1986). Regrowth following defoliation was simulated for 3 dates of defoliation in each growing season. These dates were 45,60 , and 75 days after growth began and corresponded to when grasses were grazed in the field, about 15 May, 1 June, 15 June. Verification exercises were repeated with defoliation dates varied \pm 5 days because of the uncertainty in observed defoliation dates with respect to the initiation of growth, and of the strong effect of defoliation date on the size of tillering pulses in the model (Fig. 2b).

At each simulated defoliation, $55 \%$ of the nondefoliated tillers were "grazed" at heights ranging from 47 to $90 \mathrm{~mm}$. This simulated $50-70 \%$ removal of the current season's herbage production.

Plot-level biomass predictions were validated against the results of an independent clipping experiment (Cook et al. 1958). Plotlevel predictions aggregated growth responses of tiller cohorts. In the study by Cook et al., tussocks of crested wheatgrass were defoliated 1 to 11 times during the spring and early summer of 5 consecutive years. Data from the first year (1949) were used to validate our model because production in subsequent years was subject to cumulative treatment effects. September through May precipitation in 1948-1949 $(390 \mathrm{~mm})$ was similar to our wet winter of 1982-1983.

To minimize the differences between the experimental procedures that affected Cook et al.'s observations and our model predictions, the seasonal decline in peak growth rates of defoliated tillers was removed from the model (Fig. 1a). In Cook et al.'s study, soil moisture was maintained by periodic watering of plots whereas our model was developed from observations on a site that was not irrigated and has higher summer temperatures. Because Cook et al. combined spring and summer growth in a fall harvest, we also simulated a fall harvest.

\section{Results and discussion of model performance}

The predicted growth (height) of nondefoliated tillers was similar to the observed (Fig. 3). The slightly lower predicted growth in 1984 could have been due to a dry May at the field site followed by 
substantial rainfall ( $49 \mathrm{~mm}$ ) in early June that may have contributed to the observed late season growth. The model did not include June precipitation. The average predicted sizes of the tillering pulses in the 3 years were similar to those observed $(r=0.94, n=7$, Fig. 4).

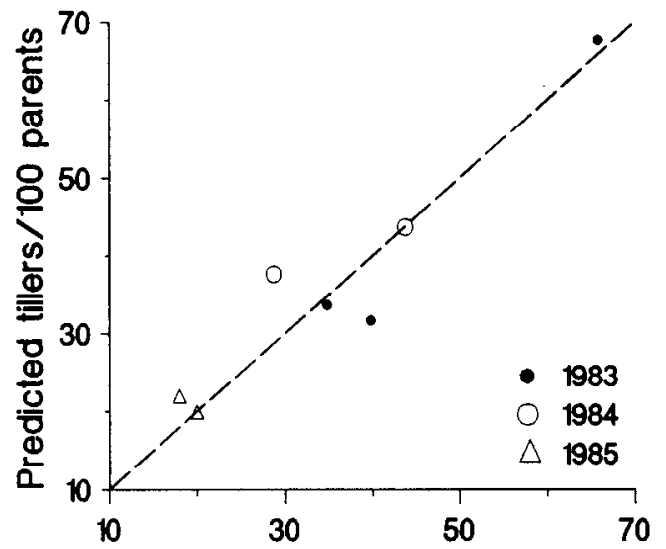

Observed tillers $/ 100$ parents

Fig. 4. Observed and predicted new tiller pulses from 1983 - 1985.

The predicted heights of defoliated tillers were also similar to the observed (Fig. 5), and were neither consistently lower nor higher than the observed. Tillers defoliated in early spring usually grew more in the following month than those defoliated later.

Predicted and observed plot-level production are shown in Figure 6. After adjusting for differences in experimental procedures, predicted production was similar to the observed $(r=0.80, n=35$, solid circles, Fig. 6), although predicted production of plots initially defoliated after 1 June was lower than the observed production ( $n=8$, open circles, Fig. 6). With the near optimal conditions in Cook et al.'s study, defoliated tiller regrowth or new spring tiller growth probably continued into summer (see Caldwell et al. 1981). Midsummer growth under watered conditions probably explains why our model, which had minimal summer growth, underpredicted production for plots defoliated in early summer. On sites with higher annual precipitation or abundant summer precipitation and cooler temperatures, e.g., high elevation seedings (Currie and Smith 1970), growth could continue through summer. Since grazing of crested wheatgrass on Intermountain rangelands normally begins in late April or early May and ends before early July, the discrepancy between our model predictions and Cook et al.'s observations following late-spring defoliations does not limit the validity of the model for applications in the Intermountain region.

Models have a valid domain, a range of input variables with which reasonably accurate model predictions can be expected. Validation of a grazing system-level model, based on this model, indicated that the valid domain consisted of cold-desert foothill pastures with 175 to $410 \mathrm{~mm}$ September-May precipitation (Senft 1988). Below $175 \mathrm{~mm}$, inadequate soil moisture recharge would limit spring growth and tillering. Above $410 \mathrm{~mm}$, especially where precipitation continues into summer, there would probably be considerable regrowth following grazing. However, our model is based on observations from a semi-arid rangeland where late spring decreases in tiller pulses and growth rates limit regrowth. Finally, because in our model grass growth and regrowth is based on winter precipitation, it is probably not applicable where springearly summer rains provide most of the annual precipitation, e.g., Great Plains. Crested wheatgrass has seldom been seeded on rangelands with precipitation less than $230 \mathrm{~mm}$ or greater than $380 \mathrm{~mm}$
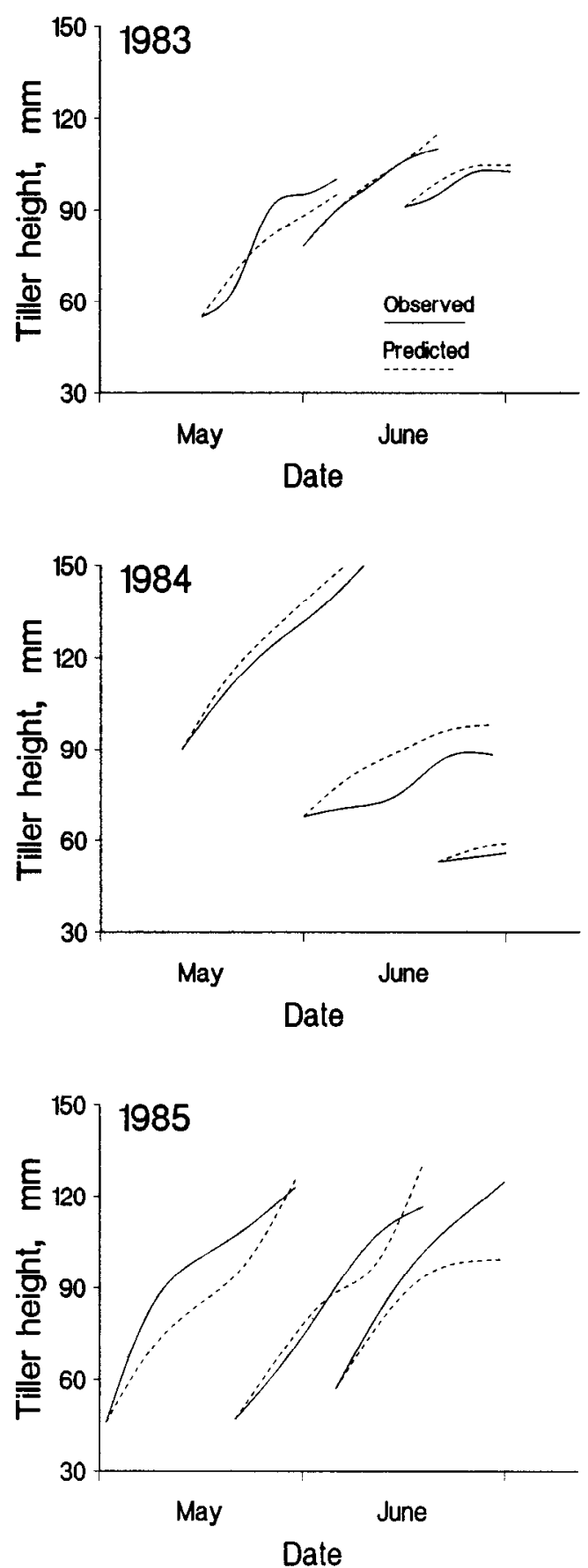

Fig. 5. Observed and predicted regrowth (height $\mathrm{mm}$ ) of tillers defoliated 15 May, 1 June, and 16 June. Regrowth periods depicted are one month. Observed data are means of 150 tillers in 1983 (10 tillers/plant, 15 plants) and 100 tillers (10 tillers/plant, 10 plants) in 1984 and 1985; adapted from Olson 1986.

(Rogler and Lorenz 1983). Thus, the model's valid domain covers the range of precipitation regimes where it is normally seeded.

Often models simulating grass growth and regrowth following defoliation give adequate simulations of data used in developing the model, but comparisons with an independent data set are not performed (Coughenour et al. 1984, 1985a,b; Johnson and Parsons 1985; Chen 1986). When validation is possible, predicted responses sometimes compare unfavorably with observed responses (Dayan et al. 1981). The successful verification and validation of our tiller-based model by observations from 2 different sites and a number of years indicates that crested wheatgrass is relatively 


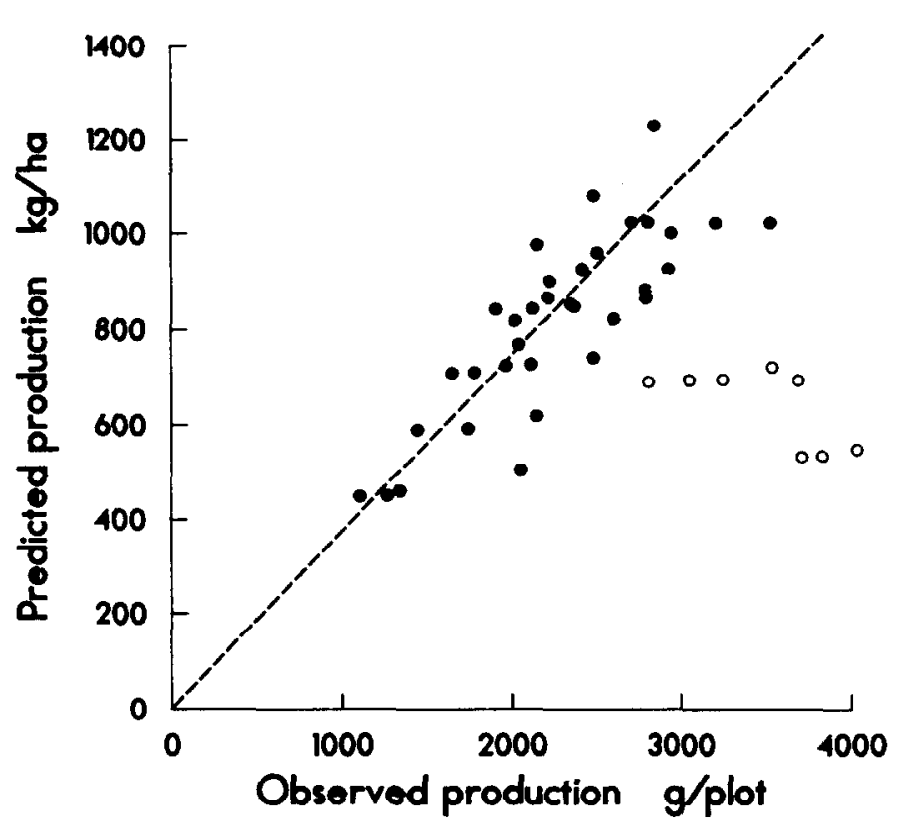

Fis. 6. Predicted and observed seasonal plot-level production. Data for observed production are from Cook et al. (1958). Solid circles indicate plots that were initially defoliated before 1 June. Open circles indicate plots that were initially defoliated on or after 1 June.

predictable in its response to defoliation, and the model can be used for plot-level simulation experiments within the valid domain.

\section{Simulation Experiments}

\section{Methods}

\section{Grazing Compensation Simulation}

To assess the effect of "time" of grazing on the degree of compensation by crested wheatgrass, single defoliations, from 5 to 95 days (at 1-day intervals) after spring growth started, were simulated. The series of simulations was run for an average winter $(300 \mathrm{~mm}$ September-May precipitation). A run with no defoliation was the control. In each trial, $50 \%$ of the standing crop was removed. A standard clipping height of $55 \mathrm{~mm}$ simulated the average observed grazing heights of crested wheatgrass by cattle at our field site (K. Olson 1986). To remove a constant $50 \%$ of standing crop, the model simulated a defoliation of 80 (early spring) to 62 (late) percent of the tillers as plant heights increased during the growing season.

Model responses were assessed at the "plot" level and thus represented a summation of responses across all tiller populations. Response variables were: (1) end-of-season tiller density (tillers $/ \mathrm{m}^{2}$ ); (2) mean plot-level relative growth rate (RGR, $\mathrm{mg} \mathrm{g}^{-1} \mathrm{~d}^{-1}$ ); (3) seasonal biomass production ( $\mathrm{kg} / \mathrm{ha}$ ) including biomass removed by defoliation; and (4) end-of-season standing crop (kg/ha).

Mean plot-level RGR (G) was calculated by averaging day-today instantaneous growth rates:

$$
\mathrm{G}=\left(\left(\mathrm{BM}_{\mathrm{t}+1}-\mathrm{BM}_{\mathrm{t}}+\mathrm{BR}\right) * \mathrm{BM}_{\mathrm{t}}^{-1}\right) * \mathrm{~L}^{-1} * 1,000 \mathrm{mg} / \mathrm{g}
$$

where $\mathrm{BM}_{t}$ was current total biomass, $\mathrm{BR}$ was biomass removed by defoliation, and $L$ was length of the growing season $(L=100 \mathrm{~d})$. To determine the contribution of new spring tillers to production, the experiment was repeated without the tillering subroutine.

\section{Grazing Optimization Simulation}

To assess whether grazing optimization (maximum production at some non-zero grazing frequency and intensity) occurs with crested wheatgrass, the frequency and intensity of defoliation were varied in a factorial design. Simulated plots were defoliated 1 to 6 times in a 60-day grazing season, about 1 May to 30 June. Because
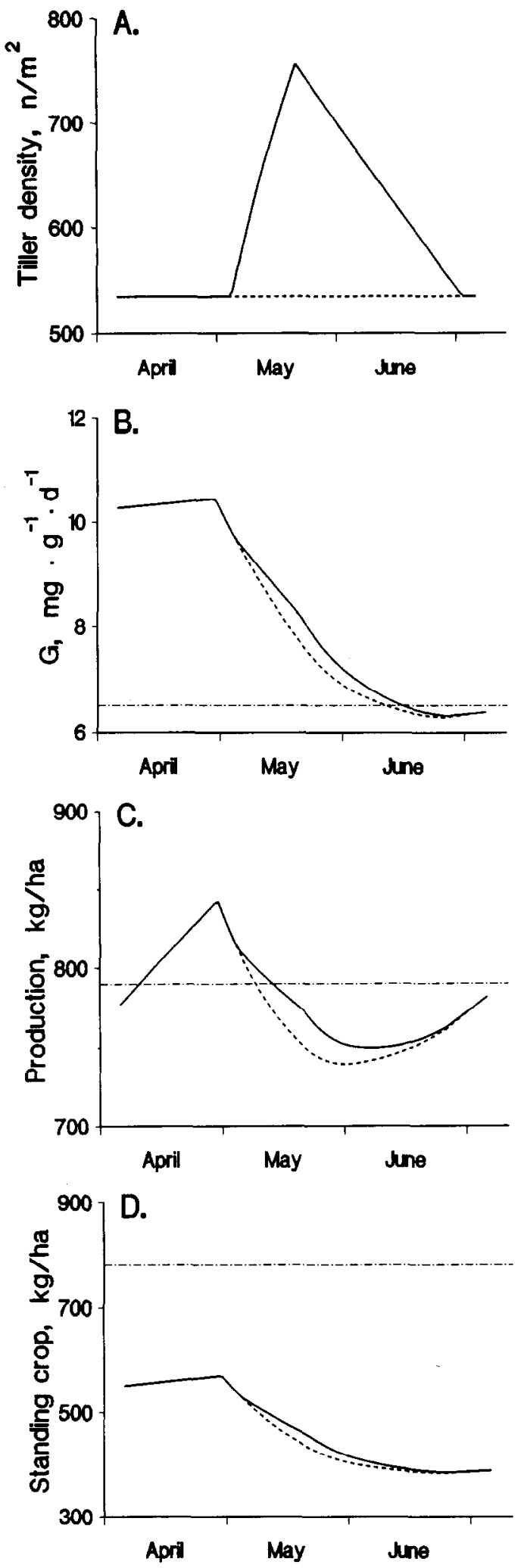

Fig. 7. Effect of date of simulated defoliation on growth responses of crested wheatgrass. a. end-of-season tiller density (initial density $=535$ tillers $/ \mathrm{m}^{2}$ ), b. mean plot-level relative growth rate $(G)$, c. seasonal biomass production, and d end-of-season standing crop. Each point along the solid and dotted lines represents the growth or population response of a single plot defoliated at a particular date. Responses of a series of defoliated plots with and without normal spring tillering are indicated by solid and dotted lines, respectively. The difference between the solid and dotted lines indicates the contribution of new spring tillers to production. Dashed lines indicate the response of a single undefoliated plot (the control). 
the previous simulation emphasized the importance of defoliation date, we averaged model responses for 3 runs at each frequency. The first run assumed even spacing of defoliation events within the grazing season, whereas defoliation events in the other 2 runs were shifted 10 (frequency $=1$ ) to days (frequency $=6$ ) before and after the dates in the first run.

Defoliation intensity was varied from $10-90 \%$ of standing herbage. Standard clipping height was again $55 \mathrm{~mm}$. The proportion of tillers defoliated was varied to obtain the desired grazing intensity, which generally parallels the grazing pattern observed in the field. At the heaviest grazing intensities, clipping heights were reduced to ojtain the desired intensities. The lowest clipping height was $17 \mathrm{~mm}$. This was above an estimated $5 \mathrm{~mm}$ minimum cropping limit of domestic cattle (Olson et al. 1986).

The simulation experiment was repeated for dry, normal and wet winters $(200,300,400 \mathrm{~mm}$ September-May precipitation). Controls consisted of ungrazed simulations run under each winter type. In each run, tiller population, height and biomass dynamics were monitored. The model responses of interest were the same as in the first experiment.

\section{Results}

\section{Grazing Compensation}

The influence of defoliation date on end-of-season tiller density was mediated by the seasonal control of tillering pulse size (Fig. 2b). Defoliations before early May did not stimulate new spring tiller emergence (Fig. 7a). Predicted new tiller production, and thus tiller density, was greatest when defoliations occurred in mid- to late May. New spring tiller emergence was not stimulated by defoliations after 1 July. This is consistent with our field observations (Olson and Richards 1988a) and probably resulted from low soil moisture availability.

Mean plot-level RGRs (G) following different times of defoliation were mediated by several factors. First, peak growth rates of defoliated parent tillers declined after mid-May (Fig. 1a). Second, tiller pulses added to mean plot-level RGR in mid-season (Fig. 2b), but this was only a minor contribution. Overall, mean plot-level RGR was highest in plots defoliated early in the growing season when regrowth was primarily from the continued growth of defoliated parent tillers (Fig. 7b). When defoliation occurred after early May, mean plot-level RGR declined because of the seasonal reduction in growth rates of defoliated parent tillers, and the negligible contribution from new spring tillers. Defoliation increased mean plot-level RGR above those of ungrazed plots, except when it occurred after early June.

Although mean plot-level RGR is increased simply by reducing biomass (the denominator in $\mathrm{mg} \mathrm{g}^{-1}$ ) following defoliation, seasonal production was higher than the controls when grasses were defoliated before early May (Fig. 7c). Production, including biomass removed by defoliation, varied between 85 and $110 \%$ of nondefoliated plots. Overall, new tillers contributed little to seasonal production (Fig. 7c). Because tussocks compensated following early spring defoliations, end-of-season standing crop was constant for plots defoliated before early May (Fig. 7d). For plots defoliated later, standing crop was lower because grass regrowth was limited by declines in tiller growth rates. In addition, the pulse of new spring tillers contributed little to end-of-season biomass.
Dry year
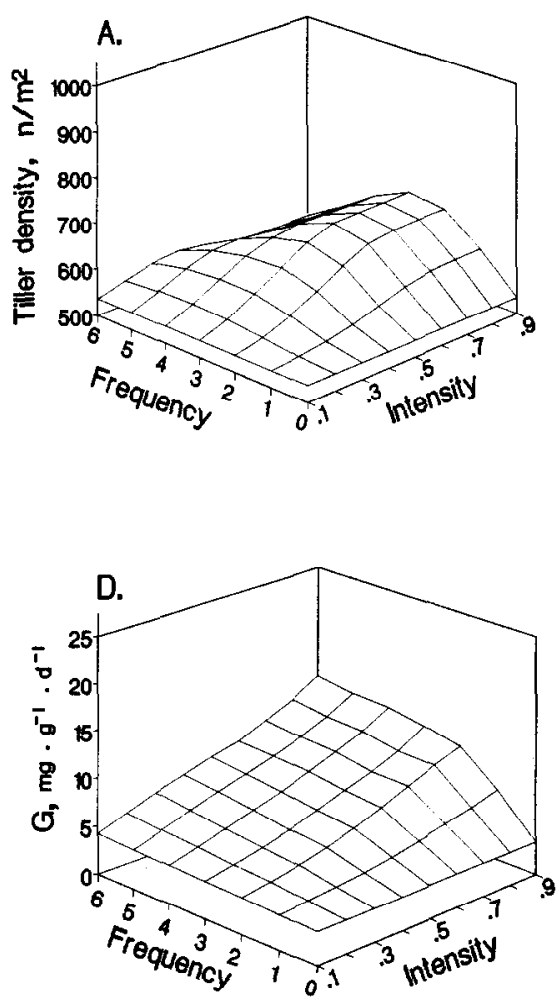

Average year
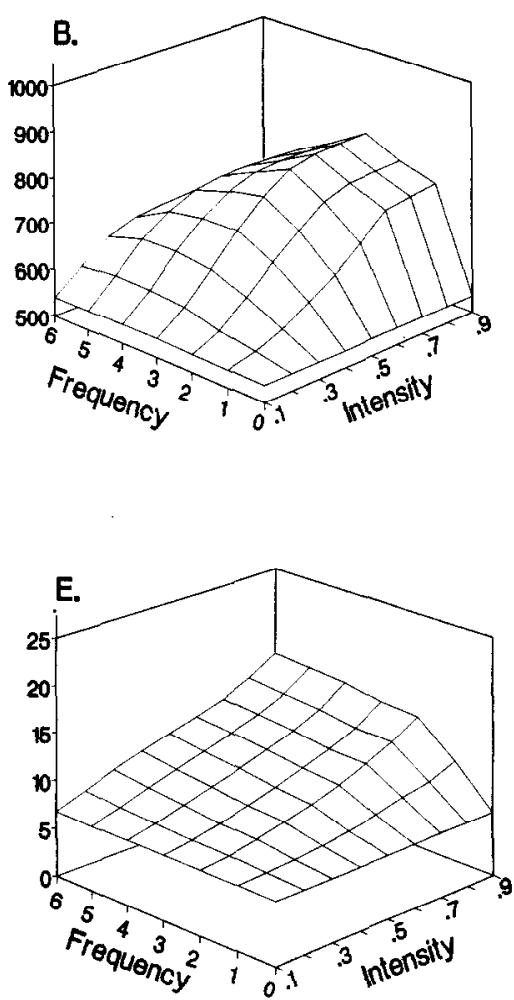

Wet year
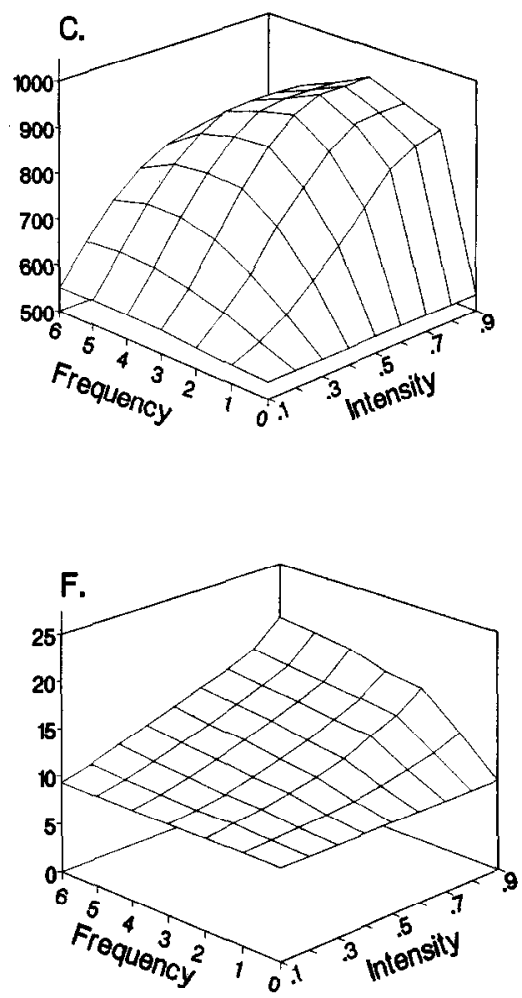

F15. 8. Effects of defoliation frequency and intenstty, and prectpitation, on growth and regrowth of crested wheatgrass. a-c. End-of-season tiller density (initial density $=535$ tillers $/ \mathrm{m}^{2}$ ), and $d-f$. mean plot-level $R G R(G)$ for dry, average and wet years. The points associated with zero defoliation frequency represent an ungrazed control. 


\section{Grazing Optimization}

For all combinations of precipitation and grazing intensity, maximum tillering occurred when plants were defoliated 3 times (Fig. 8a-c), resulting in peak tiller densities of 680, 813, and 931 tillers $/ \mathrm{m}^{2}$ for $\mathrm{dry}$, average, and wet winters. Tillering tended to increase with defoliation intensity; however, after a dry winter simulation, tillering was reduced at all defoliation intensities when plants were defoliated more than 3 times (Fig. 8a). This reduction in tillering with increased defoliation frequency was less evident after normal and wet winters (Fig. 8b,c).

Predicted mean plot-level RGR increased monotonically with increasing frequency and intensity of defoliation (Fig. 8d-f). This response resulted primarily from the increased relative growth rates of defoliated parent tillers; new spring tillers contributed little to plot growth rates. Enhanced relative growth rates of defoliated tillers mainly reflect lower available biomass following defoliation, however, and not high absolute growth rates. Lower remaining biomass makes relative growth rates large even when increases in absolute growth rates are small. Precipitation was a scalar to herbage growth rates, particularly for baseline growth rates of undefoliated tillers (frequency $=0$ in Figs. 8d-f).

Predicted seasonal biomass production was generally stable at moderate defoliation intensities, but declined at the heaviest intensities (Fig. 9a-c). After wet and average winters, production declined with increasing frequency of defoliation whereas frequency had little effect on production after the dry winter. Following dry winters, defoliated plots generally produced more than undefoliated plots (Fig. 9a). As precipitation increased, defoliation depressed biomass production relative to undefoliated controls (Fig. 9b,c).

End-of-season standing crop declined with increasing defoliation frequency and intensity (Fig. $9 \mathrm{~d}-\mathrm{f}$ ). Winter precipitation again was a scaling variable. The nonlinear response to defoliation intensity indicated that new spring tillers emerged and grew at moderate grazing intensities without reducing the regrowth of defoliated tillers.

\section{Discussion}

\section{Constraints on Regrowth}

The general agreement between predicted and observed responses of verification (our 1984 data) and validation (data from Cook et al. 1958 within the valid domain) simulations reflects the empirical basis of the model and the inherent biological constraints on growth in the field. In many grass production models, grass response to the timing of a defoliation often depends primarily on environmental factors (Johnson and Thornley 1983, Johnson and Parsons 1985, Chen 1986, Parsons et al. 1988), deemphasizing the potential importance of morphological or developmental constraints on regrowth. This approach is appropriate for species where developmental constraints are minor and thus the environment strongly affects regrowth, but for crested wheatgrass developmental constraints seem to be important, at least at certain times of the year (Richards and Caldwell 1985, Olson and Richards 1988a). Such constraints were included in this model; for example, tillering occurred primarily when the grasses were defoliated during a time corresponding to the elevation of apical meristems (but
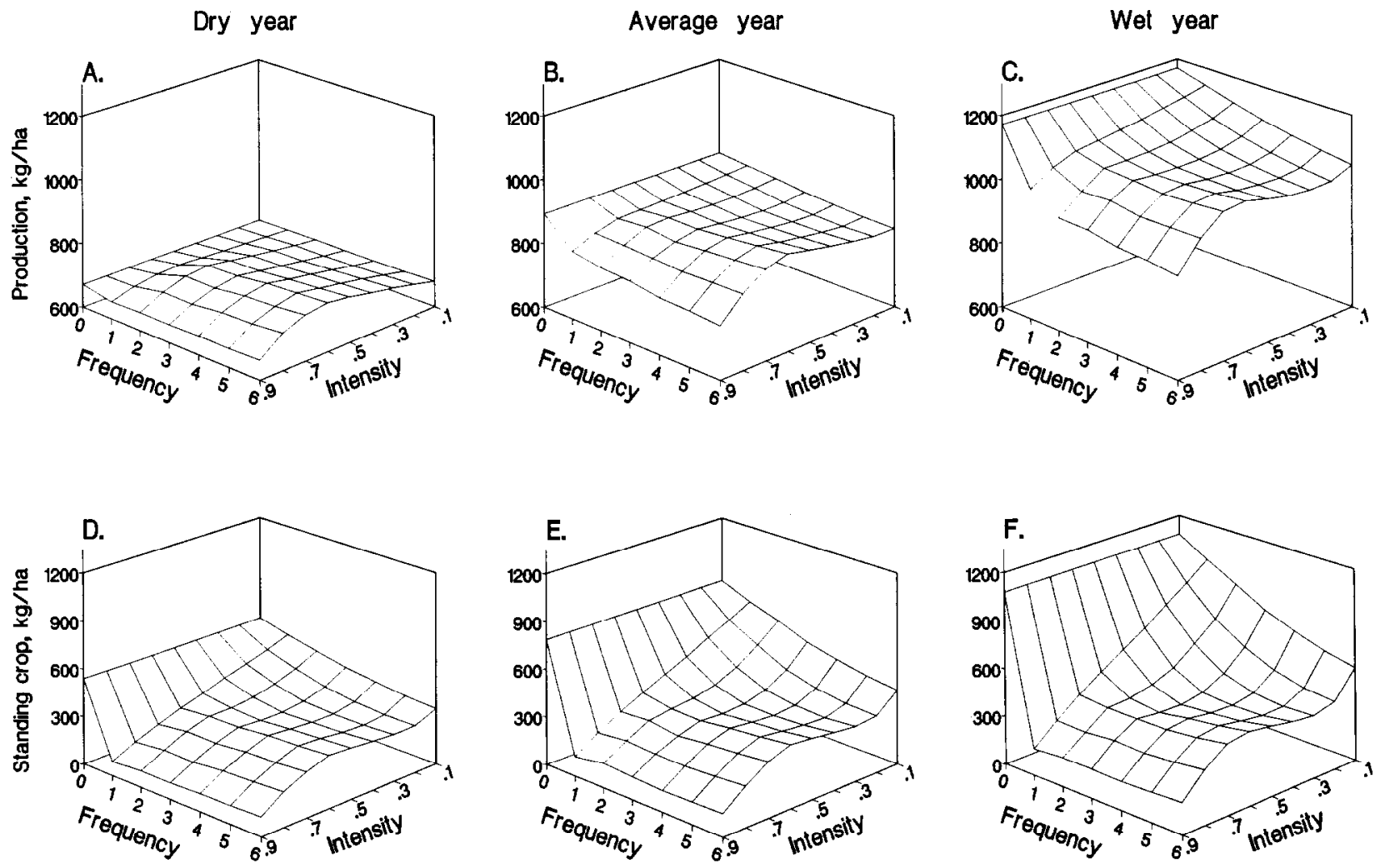

Fig. 9. Effects of defoliation frequency and intensity, and precipitation, on growth of crested wheatgrass. a-c. Seasonal production, and d-f. end-of-season standing crop for dry, average and wet years. The points associated with zero defoliation frequency represent an ungrazed control. Note: To successfully interpret response surfaces, the lowest point of the surface should face the reader. Thus, $X$ and $Y$ axes are reversed from Fig. 8. 
see Richards et al. 1988). Tillering was not based explicitly on assimilate supply (Dayan et al. 1981, Coughenour et al. 1984, 1985a).

These constraints resulted in a reduction in plot-level herbage growth rate following late spring defoliations (Fig. 7b). Models based on a plentiful supply of water and nutrients often do not incorporate a seasonal decline in growth rates following defoliation (Dayan et al. 1981, Coughenour et al. 1985a). In a previous model of crested wheatgrass, Senft and Malechek (1985) assumed that there was a constant addition to available forage when it was grazed at any time in spring. In contrast, our model incorporates limited opportunity for regrowth with late-season defoliations. This limited response is more appropriate in cold-desert regions with a short spring growing season that depends on winter precipitation. Grazing management decisions would differ considerably depending on whether regrowth is constant or declines following late spring defoliations.

\section{Grazing Compensation}

The results of this simulation indicated that compensation after grazing in this tussock grass is not constant but varies. When crested wheatgrass was defoliated once before early May, there was overcompensation in aboveground production (Fig. 7c). This defoliation enhanced the growth rates of defoliated tillers relative to undefoliated tillers (Fig. 1b, Olson and Richards 1988a). Cook et al. (1958) also observed overcompensation after early spring defoliation of crested wheatgrass. Furthermore, they observed overcompensation after late spring defoliations, but this probably resulted from the supplemental watering of their grasses.

Although defoliation enhanced mean plot-level RGR, overcompensation in seasonal production occurred only after early spring defoliations (Fig. 7c, compare McNaughton et al. 1983, McNaughton 1985, Belsky 1986). Early spring defoliations allowed enough time for enhanced growth rates to produce considerable amounts of new foliage, thus increasing seasonal production. Because compensatory growth rates are often short-lived (Olson and Richards 1988a), assessments of compensatory growth should be based on seasonal or annual production, the integration of growth rates through time.

The potential enhancement of mean plot-level RGR (Fig. 7b) and available foliage declined as the season progressed, thereby lowering regrowth and seasonal production (Fig. 7c). Carbohydrate reserves available for regrowth are highest when we observed and simulated this seasonal decline in regrowth (Caldwell et al. 1981, Deregibus et al. 1982, Richards and Caldwell 1985, Olson and Richards 1988a). Our observations and simulations indicate that regrowth depends primarily on the efficiency of carbon utilization for shoot production and photosynthetic area, but not on mobilizing large carbohydrate reserves. At least for crested wheatgrass, shoot regrowth efficiency depends on shoot meristem activity, and concurrent photosynthesis contributes considerably more carbon to regrowth than carbohydrate reserves contribute (Richards and Caldwell 1985).

Although the model is empirically based, the responses agree with the theoretical constructs of Hilbert et al.'s (1981) analysis of relative growth rates. Overcompensation after early-spring defoliation indicated that crested wheatgrass can increase relative growth rates of defoliated tillers considerably above the rates of undefoliated tillers. After mid-spring defoliation, when undefoliated plants were growing rapidly, the large increase in relative growth rates of defoliated tillers needed for compensation were not realized, possibly because of developmental constraints. After latespring defoliation, when undefoliated grasses were growing slowly, only a small increase ingrowth rates of defoliated tillers would have been necessary to equal the productivity of ungrazed tillers (Hilbert et al. 1981). Yet such compensation did not occur in our model nor was it observed (Olson and Richards 1988a), presumably because low soil moisture, high temperatures, or both limited tillering and growth rates of defoliated tillers in late spring.

Mid-spring defoliation reduced the seasonal production of crested wheatgrass, as others have noted (Cook et al. 1958, Miller et al. 1984), because of declining growth rates of defoliated tillers and the negligible contribution from new spring tillers. Although new spring tillers contributed little to forage production and senesced in summer, they probably increased the number of axillary buds available for fall tiller production and thus annual tiller replacement (Olson and Richards 1988b).

\section{Grazing Optimization}

With extensive management, single early- or late-spring defoliations that result in overcompensation are possible, but these would occur at the start and the end, respectively, of a typical spring grazing season in the Intermountain region. With intensive management, individual tussocks could be grazed several times during the spring growing season. In some grasses, grazing at some frequency and intensity may increase net primary production above that of ungrazed plots (i.e., grazing optimization, McNaughton 1979), yet there was little evidence that a particular grazing frequency-intensity combination would increase primary production in crested wheatgrass. Only after a dry winter was simulated seasonal productivity slightly greater with "grazing" than without (Fig. 9a).

For full compensation after defoliation to occur, mean plot-level RGRs should have been an exponential function of grazing intensity (Hilbert et al. 1981). However, we found that mean plot-level RGRs were generally a linear function of grazing intensity, thus full compensation would not have been expected following defoliation. This agrees with the limited conditions where the model predicted full compensation or where it has been observed in the field with crested wheatgrass (Cook et al. 1958, Olson and Richards 1988a). The positive relationship between grazing intensity and mean plot-level RGR was not entirely linear. The highest grazing intensity $(0.9)$ in our model was least, not most, likely to increase productivity above ungrazed tussocks, presumably because the required increase in growth rate was not biologically possible. Moderate grazing intensities, in this and Hilbert et al.'s (1981) model, generally increased production more than heavy or light defoliation intensities (Fig. 9a-c).

Low defoliation frequencies should result in greater compensation than high frequencies because greater growth increases are needed at high frequencies (Hilbert et al. 1981). Our model responses tended to agree with this prediction when defoliation intensity was light or heavy after average and wet winters. In the dry winter simulation, however, frequent moderate defoliations increased production more than infrequent defoliations (Fig. 9a). This latter response reflects another postulate of Hilbert et al. (1981) that smaller growth rate increases are needed to achieve compensation when growth is limited, e.g., after a dry winter, than when grasses are rapidly growing under favorable conditions.

Our model indicated that grazing tolerance, for which crested wheatgrass is well known (Caldwell et al. 1981), does not necessarily translate into the potential for grazing optimization of net primary productivity. McNaughton (1979) suggested that grazing optimization is not possible with domestic livestock as in our model because the grasses and grazers have not evolved together. Alternatively, crested wheatgrass tillers are taller and less dense than those of Kyllinga nervosa (McNaughton et al. 1983). These morphological differences may partially explain why defoliation failed to consistently increase net primary productivity in crested wheatgrass (Coughenour et al. 1985b). Even in Kyllinga, however, grazing does not consistently maximize productivity (McNaughton 1979). 
With our empirical simulation model, we developed response surfaces for several herbage variables to determine if compensation might be expected from grazed tussocks of crested wheatgrass, and to test whether McNaughton's grazing optimization hypothesis describes crested wheatgrass regrowth following 3 types of winters. The time of defoliation, incorporating developmental and environmental factors, determined the extent of compensation. Further, except after the driest winter there was no evidence for a combination of non-zero grazing intensity and frequency that maximizes seasonal herbage production.

\section{Literature Cited}

Belaky, A.J. 1986. Does herbivory benefit plants? A review of the evidence. Amer. Natur. 127:870-892.

Belaky, A.J. 1987. The effects of grazing: confounding of ecosystem, community, and organism scales. Amer. Natur. 129:777-783.

Buseo, C.A. 1988. Factors affecting recovery from defolistion during drought in two aridland tussock grasses. PhD. Diss. Utah State Univ., Logan.

Caldwell, M.M. 19s5. Cold desert. p. 198-212. In: B.F. Chabot and H.A. Mooney (eds.). Physiological ecology of North American plant communities. Chapman and Hall, New York.

Caldwell, M.M., J.H. Richards, D.A. Johnoon, R.S. Nowak, and R.S. Daurec. 1981. Coping with herbivory: photosynthetic capacity and resource allocation in two semiarid Agropyron bunchgrasses. Oecologia 50:14-24.

Chen, J. 19a6. Optimal cutting frequency and intervals derived from Johnson and Thornley's model of grass growth. Agr. Sys. 22:305-314.

Cook, C.W., L.A. Stoddart, and F.E. Kindinger. 1958. Responses of crested wheatgrass to various clipping treatments. Ecol. Mono. 28:237272.

Coughenour, M.B., S.J. MeNaughton, andL.L. Wallace. 1984. Modelling primary production of perennial graminoids-uniting physiological processes and morphometric traits. Ecol. Model. 26:101-134.

Coughenour, M.B., S.J. MeNaughton, and L.L. Wallace. 1985a. Simulation of East African perennial graminoid responses to defoliation. Ecol. Model. 26:177-202.

Couphenour, M.B., S.J. MeNaughton, and L.L. Wallace. 1985b. Shoot growth and morphometric analyses of Serengeti graminoids. African J. Ecol. 23:179-194.

Currie, P.O., and D.W. Smith. 1970. Response of seeded ranges to different grazing intensities in the ponderosa pine zone of Colorado, USDA For. Serv. Prod. Res. Rep. 112.

Dayan, L., H. Van Keulen, and A. Dovrat. 1981. Tiller dynamics and growth of Rhodes grass after defoliation: a model named TILDYN. Agro-Ecosys. 7:101-112.

Dereqlbus, V.A., M.J. Trlica, and D.A. Jameson. 1982. Organic reserves in herbage plants: their relationship to grassland management. p. 315-344. In: M. Recheigl (ed.), CRC Handbook of Agricultural Productivity, Vol I, Plant Productivity. CRC Press, Boca Raton, Fla.

Friachkneeht, N.C., and L.E. Harrs. 1968. Grazing intensities and systems on crested wheatgrass in central Utah: response of vegetation and cattle. USDA Forest Serv. Tech. Bull. 1388.

Grant, W.E. 1986. Systems analysis and simulation in wildlife and fisheries science. Wiley-Interscience, New York.

Hibert, D.W., D.M. Switt, J.K. Detling, and M.I. Dyer. 1981. Relative growth rates and the grazing optimization hypothesis. Oecologia 51:14-18.

Johnson, I.R., and A.J. Parwons. 1985. Use of a model to analyse the effects of continuous grazing management on seasonal patterns of grass production. Grass and Forage Sci. 40:449-458.

Johneon, I.R., and J.H.M. Thormley. 1923. Vegetative crop growth model incorporating leaf area expansion and senescence, and applied to grass. Plant, Cell and Envir. 6:721-729.

Johmson, P.S. 1987. Utilization of plants of crested wheatgrass by cattle under several grazing regimes. Ph.D. Diss. Utah State Univ., Logan.
Mack, R.N., and J.N. Thompeon. 1982. Evolution in steppe with few, large hooved mammals. Amer. Natur. 119:757-773.

Malechek, J.C., and D.D. Dwyer. 1983. Short duration grazing doubles your livestock? Utah Sci. 44:32-37.

MeNaughton, S.J. 1979. Grazing as an optimization process: grassungulate relationships in the Serengeti. Amer. Nat. 113:691-703.

MeNaughton, S.J. 1983. Compensatory plant growth as a response to herbivory. Oikos 40:329-336.

McNaughton, S.J. 1935. Ecology of a grazing system: the Serengeti. Ecol. Mono. 55:259-294.

McNaughton, S.J., L.L. Wallace, and M.B. Coughenour. 1983. Plant adaptation in an ecosystem context: effects of defoliation, nitrogen, and water on growth of an African C. sedge. Ecology 64:307-318.

Miller, R.F., M.R. Hafertamp, and R.F. Angell. 1944. Defoliation and growth of crested wheatgrass. I. Defoliation effects on forage growth, p. 12-17. Research in beef cattle nutrition and management. Oregon $A g r$. Exp. Sta. Spec. Rep. 714.

Muezaler, W.F. 1972. Influence of competition on the response of bluebunch wheatgrass to clipping. J. Range Manage. 25:88-92.

Mueller, R.J., and J.H. Richards. 1986. Morphological analysis of tillering of Agropyron spicatum and Agropyron desertorum. Ann. Bot. 57:91 1-921.

Norton, B.E., and P.S. Johnion. 1983. Pattern of defoliation by cattle grazing crested wheatgrass pastures. p. 422-424. In. J.A. Smith and V.W. Hayes (eds.), Proc. XIV Grassl. Cong., Westview Press, Boulder, Colo.

Oleon, B.E. 1986. Tiller dynamics of Agropyron desertorum in response to grazing and resource manipulation. Ph.D. Diss., Utah State Univ., Logan.

Olson, B.E., and J.H. Rlchards. 1988. Tussock regrowth after grazing: intercalary meristem and axillary bud activity of tillers of Agropyron desertorum. Oikos 51:374-382.

Oleon, B.E., and J.H. Richards. 1938b. Annual replacement of the tillers of Agropyron desertorum following grazing. Decologia 76:1-6.

Oleon, B.E., and J.H. Richards. 1989. Crested wheatgrass growth and replacement following fertilization, thinning and neighbor removal. J. Range Manage. 42:93-97.

Olson, K.C. 1986. Animal nutritional response to sward structure under short duration grazing management. Ph.D. Diss., Utah State Univ., Logan.

Olson, K.C., R.L. Senf, and J.C. Malechek. 1986. A predictive model of cattle ingestive behavior in response to sward characteristics. p. 259-261. In: Proc. West. Sect. Amer. Soc. Anim. Sci. 37:259-261.

Parsons, A.J., I.R. Johnson, and A. Harvey. 1988. Use of a model to optimize the interaction between frequency and severity of intermittent defoliation and to provide a fundamental comparison of the continuous and intermittent defoliation of grass. Grass and Forage Sci. 43:49-59.

Rlcharda, J.H., and M.M. Caldwell. 1985. Soluble carbohydrates, concurrent photosynthesis and efficiency in regrowth following defoliation: a field study with Agropyron species. J. Appl. Ecol. 22:907-920.

Richards, J.H., R.J. Mueller, and J.J. Mott. 1988. Tillering in tussock grasses in relation to defoliation and apical bud removal. Ann. Bot. 62:173-179.

Ropler, G.A., and R.J. Lorenz. 1983. Crested wheatgrass - early history in the United States. J. RangerManage. 36:91-93.

Senf, R.L. 1988. Short duration grazing on crested wheatgrass (Agropyron desertorum): effects of grazing system variables on cattle and herbage production. Agr. Sys. 28:189-211.

Senft, R.L., and J.C. MalecheK. 1985. Short duration grazing cell parameters and cattle production: a low-resolution model. Proc. West. Sect. Amer. Soc. Anim. Sci. 36:282-285.

Sneva, F.A., and D.N. Hyder. 1961. Estimating herbage production on semiarid ranges of the Intermountain region. J. Range Manage. 15:88-93.

West, N.E. 1983. Overview of North American temperate deserts and semi-deserts. p. 321-330. In: N.E. West (ed), Temperate Deserts and Semideserts, Elsevier, Amsterdam.

White, J. 1979. The plant as a metapopulation. Ann. Rev. Ecol. Sys. 10:109-145. 